\title{
Reappraisal of the primitive crab Eodromites, with description of three new species from European localities (Decapoda: Brachyura: Goniodromitidae)
}

\author{
Natalia Starzyk
}

\begin{abstract}
The brachyuran genus Eodromites is abundant at Jurassic localities of Europe. Seven species were attributed to Eodromites hitherto, but the type material of only three of them is known. Four species are present at Oxfordian localities of Poland, including two new: $E$. rotundus n. sp. and $E$. hyznyi n. sp. One new species from Kimmeridgian of Germany is described - E. guenteri n. sp. New characters (anterior grooves, groups of hepatic pits, hepatic tubercles, three pairs of pits, length and shape of augenrest) for the genus and species are described.
\end{abstract}

Natalia Starzyk. Institute of Systematics and Evolution of Animals, Polish Academy of Sciences; ul. Sławkowska 17; 31-016 Kraków, Poland; natalia_slaby@wp.pl

Keywords: Eodromites, Homolodromioidea, Brachyura, Decapoda, new species, Jurassic, Oxfordian

Submission: 29 September 2014. Acceptance: 25 September 201

\section{INTRODUCTION}

\section{History of Research}

Eodromites was erected by Patrulius (1959) to separate Prosopon grande from species included in the genera: Prosopon von Meyer, 1835, Goniodromites Reuss, 1858 and in Pithonoton von Meyer, 1842.

Eodromites consists of 10 species (including three new described herein), however, only six are documented with type or any other material, and their generic assignment is verified. These are: $E$. grandis, $E$. aequilatus, E. dobrogea and three new described herein: E. hyznyi n.sp, E. rotundus n. sp. and E. guenteri n. sp. (Table 1).

Patrulius (1966) suggested that Prosopon rostratum may be a synonym of $E$. grandis, but in the absence of the type material and insufficient description (von Meyer, 1860) its affinity could not be confirmed. Eventually, this species was assigned to Eodromites (Schweitzer and Feldmann, 2008).

Eodromites polyphemi was assigned to Pithonoton von Meyer, 1842 by Glaessner (1929). Wehner (1988) considered the species to be conspecific with $E$. grandis, but Schweitzer and Feldmann (2008) differentiated these two species based on the angle between the plane of orbits and the long body axis, and on overall proportions of the carapace (illustrated in Gemmellaro, 1869).

The original material of $E$. nitidus and $E$. aequilatus is lost (Schweitzer and Feldmann, 2008). Both these species were assigned to Pithonoton by Glaessner (1929). The characters illustrated by Milne Edwards (1865: pl. 5, figure 1a) support affinity of the first mentioned species to 
TABLE 1. Type material of all species of the genus Eodromites ( ${ }^{*}$ type material of Eodromites dobrogea was studied on pictures in Feldmann et al., 2006, figure 3.10; Schweitzer et al., 2007, figure 4.3; Schweitzer and Feldmann, 2010, figure 5.4-6).

\begin{tabular}{|c|c|c|c|}
\hline Species & Age, locality & Type material & Examined material \\
\hline $\begin{array}{l}\text { E. aequilatus (von Meyer, } \\
\text { 1857) }\end{array}$ & $\begin{array}{l}\text { Oxfordian-Lower Kimmeridgian of } \\
\text { Germany and Poland }\end{array}$ & $\begin{array}{l}\text { holotype lost in the World War II, } \\
\text { neotype - SMNS } 67336 / 1\end{array}$ & $\begin{array}{l}\text { Material from ISEA PAN, } \\
\text { IGPUW, SMNS }\end{array}$ \\
\hline $\begin{array}{l}\text { E. depressus (von Meyer, } \\
\text { 1860) }\end{array}$ & $\begin{array}{l}\text { Upper Jurassic of eastern Swabia } \\
\text { (Germany) }\end{array}$ & lost & - \\
\hline $\begin{array}{l}\text { E. dobrogea (Feldmann et al., } \\
\text { 2006) }\end{array}$ & $\begin{array}{l}\text { Middle Oxfordian-Tithonian of } \\
\text { Romania, Czech Republic and } \\
\text { Austria }\end{array}$ & holotype - LPBIIlart-040 & $-{ }^{*}$ \\
\hline E. grandis (von Meyer, 1857) & $\begin{array}{l}\text { Upper Jurassic of Germany, Poland, } \\
\text { Czech Republic and Romania }\end{array}$ & holotype -BSP1881IX678 & $\begin{array}{l}\text { Material from ISEA PAN, } \\
\text { IGPUW, SMNS }\end{array}$ \\
\hline $\begin{array}{l}\text { E. nitidus (Milne Edwards, } \\
\text { 1865) }\end{array}$ & Lower Cretaceous of France & lost in the World War II & - \\
\hline $\begin{array}{l}\text { E. polyphemi (Gemmellaro, } \\
\text { 1869) }\end{array}$ & Tithonian of Sicily & lost & - \\
\hline E. rostratus (von Meyer, 1840) & $\begin{array}{l}\text { Upper Jurassic of Germany and } \\
\text { France }\end{array}$ & lost & - \\
\hline E. rotundus $\mathrm{n} . \mathrm{sp}$. & Oxfordian of Poland & holotype - I-F/MP/6271/1599/12 & Material from ISEA PAN \\
\hline E. hyznyi n. sp. & Oxfordian of Poland & holotype - I-F/MP/4973/1543/09 & Material from ISEA PAN \\
\hline E. guenteri n. sp. & Upper Kimmeridgian of Germany & holotype - SMNS61668/4 & Material from SMNS \\
\hline
\end{tabular}

Eodromites (Schweitzer and Feldmann, 2008). Specimens of $E$. aequilatus from the Institute of Geology, University of Warsaw, agree with the original description and illustrations of this species. According to Schweitzer and Feldmann (2008) the carapace of Eodromites aequilatus is not narrowing anteriorly and posteriorly as it is in other representatives of Pithonoton. It has also inflated subhepatic regions, which are more flat in the species of Pithonoton (Schweitzer and Feldmann, 2008). Schweigert and Koppka (2011) included this species in Eodromites and paid attention to similarities between this species and Tanidromites (Tanidromitidae).

According to Schweitzer and Feldmann (2008) the type material of Eodromites depressus is lost. It was recognized as $E$. grandis by Glaessner (1929, 1933) and Wehner (1988). Schweitzer and Feldmann (2008) separated it from E. grandis based on differences in the posterior portion of the carapace documented in description and illustrations of von Meyer (1860: pl. 23, figure 18).

Eodromites dobrogea was originally described as Cycloprosopon Lörenthey in Lörenthey and Beurlen, 1929 (Feldmann et al., 2006). Later it was transferred to Eodromites based upon similarities of the posterior part of the carapace (Schweitzer and Feldmann, 2010).

In the present paper new features diagnostic to the genus are described. The diagnosis is amended. Diagnoses and descriptions of all species included are supplemented with new characters.

\section{Current Research}

Eodromites differs from other goniodromitid genera in having a carapace short and widest behind the intersection of cervical groove and the lateral margin, a long and deep augenrest, distinct outer orbital spine and convex lateral margins, strongly narrowing posteriorly (Schweitzer and Feldmann, 2008).

Species specific characters include the shape and proportions of the carapace and its regions, shape and length of the augenrest, and development of the grooves (Schweitzer and Feldmann, 2008). As evidenced herein, particular species also differ in a ratio of distance from the end of the augenrest to the cervical groove, and in the distance from the rostrum to the cervical groove. Other characters, such as hepatic pits and tubercles, were earlier identified in Tanidromites (Starzyk, 2013), but not featured in any species of Eodromites. Studies of these characters were made on all species with available material except E. dobrogea, which was checked using figures (Feldmann et al., 2006, figure 3.10, Schweitzer et al., 2007, figure 4.3, Schweitzer and Feldmann, 2010, figure 5.4-6). Illustrations of other species ( $E$. depressus, E. nitidus, E. polyphemi, E. rostratus) 


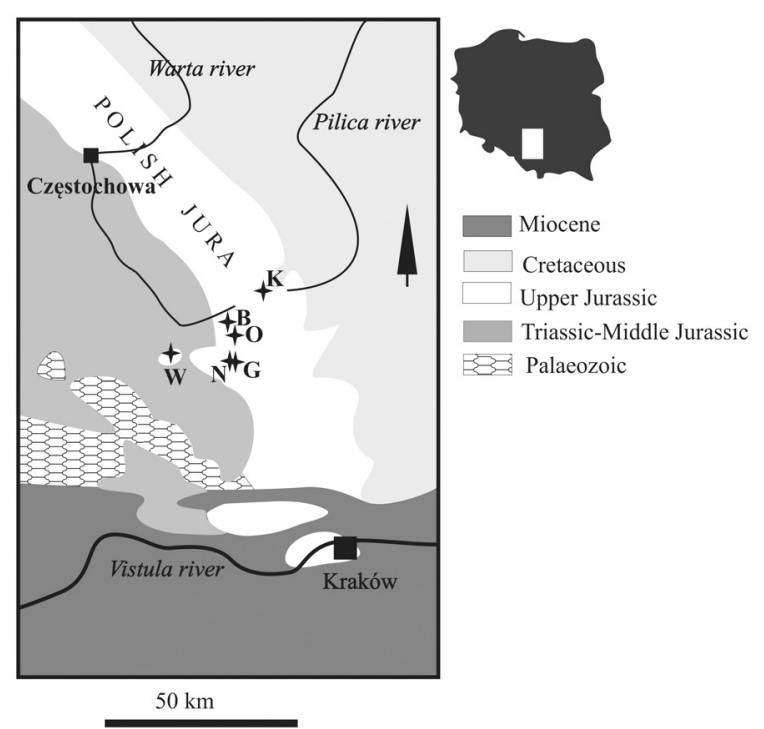

FIGURE 1. Studied area - the southern Polish Uplands, northwest of Cracow (Poland). The abbreviations of the localities B - Bzów, G - Grabowa, K - Kroczyce, N - Niegowonice, $\mathrm{O}-$ Ogrodzieniec and W Wysoka (modified after Głowniak, 2006, figure 2).

do not allow to recognize the state of these features. The groups of hepatic pits were also earlier noticed in the representatives of Cycloprosopon Lörenthey in Lörenthey and Beurlen, 1929 (Schweitzer and Feldmann, 2010, figures 2.1, 3-4, 4.6).

\section{LOCALITIES AND STRATIGRAPHY}

Specimens from the collection of IGPUW come from several localities in the Polish Jura, Wieluń Upland and the Holly Cross Mountains. Specimens from the collection of the Staatliches Museum für Naturkunde in Stuttgart (SMNS) come from several Oxfordian and Kimmeridgian localities in Germany. They were described previously (Collins and Wierzbowski, 1985; Schweigert and Koppka, 2011; Schweitzer and Feldmann, 2008).

Material from the collection of the Museum of the Institute of Systematics and Evolution of Animals, Polish Academy of Sciences in Kraków (ISEA PAN) originates from five localities in the southern Polish Uplands, northwest of Kraków (Poland), namely Bzów, Grabowa, Kroczyce, Niegowonice, Ogrodzieniec and Wysoka (Figure 1, Table 2). Specimens were collected mainly from debris massed in the bottom of the outcrops.

Stratigraphy and descriptions of localities were treated in Starzyk et al. (2012), and Starzyk (2013), and are summarized in Table 2.

\section{MATERIAL AND METHODS}

Specimens studied herein are deposited in the Museum of the Institute of Systematics and Evolution of Animals, Polish Academy of Sciences in Kraków (ISEA PAN, I-F/MP), Museum of the Gelogical Institute, University of Warszawa (IGPUW) and Staaliches Museum für Naturkunde in Stuttgart (SMNS).

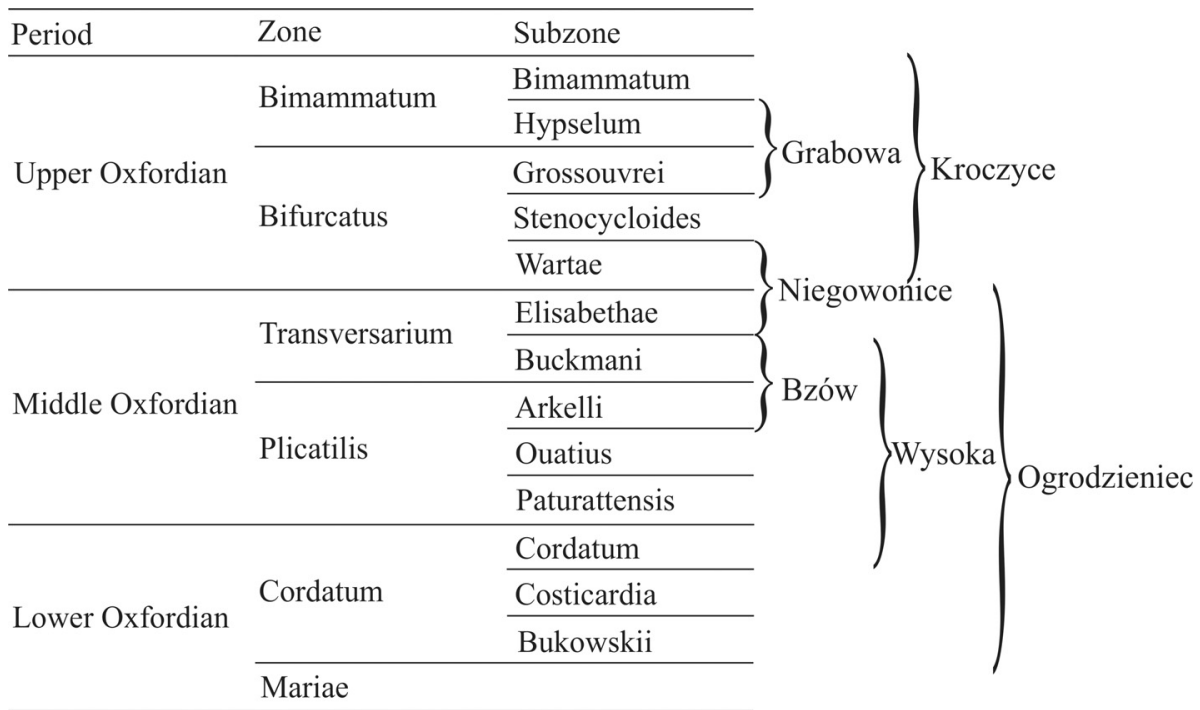

TABLE 2. Stratigrafic age of the studied localities in the Polish Upland (based upon references cited in Starzyk et al., 2012 and Starzyk, 2013). 
1

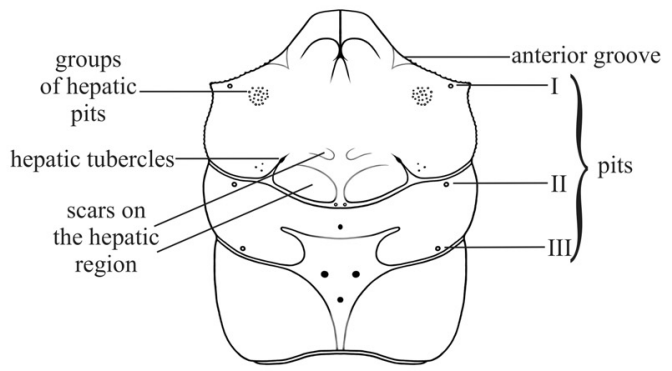

2

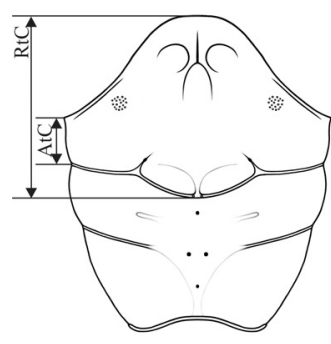

E. rotundus n. sp.

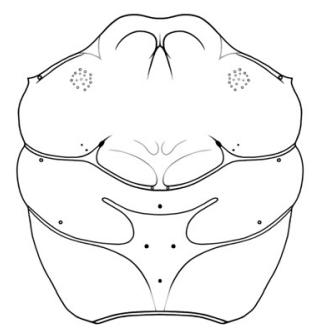

E. guenteri n. sp.

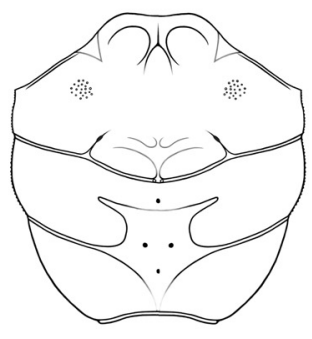

E. grandis

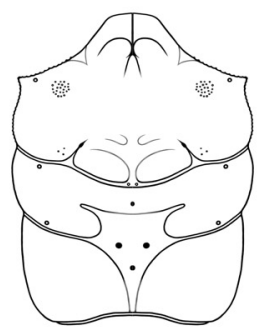

E. aequilatus

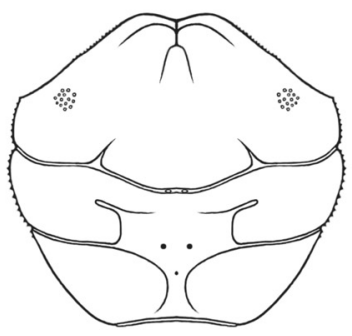

E. dobrogea

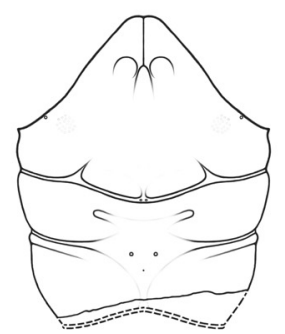

E. hyznyı n. sp.

3

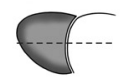

E. aequilatus

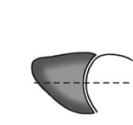

E. rotundus n. sp. posterior angle

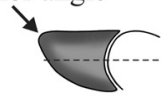

E. hyznyi n. sp.

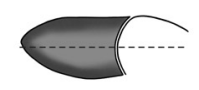

E. guenteri n. sp.

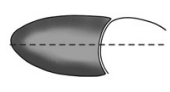

E. grandis

FIGURE 2. 1. Groundplan of the morphological structures in the species of Eodromites on the example of E. aequilatus. 2. Reconstruction of the carapace of described species of Eodromites, reconstruction of E. dobrogea is based on pictures of other authors (Feldmann et al., 2006, figure 3.10; Schweitzer et al., 2007, figure 4.3; Schweitzer and Feldmann, 2010, figure 5.4-6). 3. Comparision of shape and length of augenrest in the studied species of Eodromites. Dashed line - horizontal axis of the augenrest.

The collection of decapods housed in the ISEA contains 7000 specimens of brachyurans and anomurans, which were subject of several studies (Brachyura: Starzyk et al., 2011, 2012; Starzyk, 2013; Anomura: Fraaije et al., 2012a, b, c; Krzemińska et al., 2015). Among them, the specimens of Eodromites were found in large number ( $3,16 \%$ of the entire collection). In total, there are about 213 specimens of Eodromites determined so far (E. grandis - 190, E. hyznyi n. sp. - 7, E. rotundus n. sp. - 16), from which 44 best preserved specimens were selected for the present study.
Specimens were collected by the Borek family who are amateur collectors. Only the first numbers of specimens (in bold) are cited in the text, example: I-F/MP/6258/1588/11.

Measurements (Figure 2.1) were taken from the dorsal view. Specimens with deformations were not measured.

\section{NEW DIAGNOSTIC FEATURES}

The following species-diagnostic features were detected among material of two known and 
two new species of Eodromites and also recognized in pictures of $E$. dobrogea (Feldmann et al., 2006 figure 3.10, Schweitzer et al., 2007, figure 4.3, Schweitzer and Feldmann, 2010, figure 5.4-6).

Ornamentation of the carapace is diagnostic for fossil decapods. Presence or absence of the cuticle can alter the expression of these characters (Klompmaker et al., 2015). The cuticle is not preserved on most of the specimens studied herein. It covers the structures mentioned below only on specimen of $E$. aequilatus (No. 3558), and they are clearly visible on the surface of the cuticle of this specimen.

1) Anterior grooves in the intersection of the anterior margin of the augenrest and the carapace margin. Earlier these grooves were described in Tanidromites (Starzyk, 2013). They are conspicuous in $E$. aequilatus, weakly developed in E. grandis and E. guenteri n. sp., and absent from $E$. dobrogea, E. hyznyi n. sp. and $E$. rotundus n. sp. (Figure 2.1).

2) Groups of hepatic pits on hepatic regions. Single, symmetric hepatic pits were mentioned before in the Tanidromitidae (Schweigert and Koppka, 2011; Starzyk, 2013). In the representatives of Eodromites they form two symmetric groups (Figure 2.1-2), visible on carapaces of all five species discussed here, and on the photographs of $E$. dobrogea (Feldmann et al., 2006, figure 3.10, Schweitzer et al., 2007, figure 4.3, Schweitzer and Feldmann, 2010, figure 5.4-6). The groups of pits are also present in other genus of the Goniodromitidae - Cycloprosopon (visible also on photographs in Schweitzer and Feldmann, 2010, figures 2.1, 34, 4.6).

3) Hepatic tubercles in the hepatic grooves. They appear in all species of Eodromites except for $E$. hyznyi $\mathrm{n}$. sp. These tubercles were described earlier in Tanidromites, where they are usually more distinct (Starzyk, 2013) (Figure 2.1-2).

4) Three pairs of symmetric pits. The first (I) pair on the upper orbital margin, and two pairs on the epibranchial region - second (II) next to the cervical groove and third (III) next to the branchio-cardiac groove (Figure 2.1-2). These traces have not been observed before. All three pairs of pits are present in E. aequilatus and E. guenteri n. sp.; the I pair is present on the carapace of E. hyznyi $\mathrm{n}$. sp. In other species these pits are absent.

5) Length and shape of augenrest. The augenrest appears to be variable in crab species; diversity of this structure is also high in Eodromites. Eodromites aequilatus has relatively short augenrest assymetrical along horizontal axis, and with an elevated posterior angle. Eodromites rotundus n. sp. and E. hyznyi n. sp. have longer augenrest with an elevated posterior angle. In $E$. guenteri n. sp. and E. grandis the augenrest is still longer and more symmetric - position of the posterior angle is lower (Figure 2.3).

6) Measurements. They are indicated in Figures 2.2, 3 appeared helpful for diagnostic purposes. These are: RtC - length from the rostrum to the cervical groove and AtC - length from the edge of the outer orbital spine to the cervical groove.

These characters could not be checked in other species (E. polyphemi, E. nitidus, E. rostratus, E. depressus). Images and descriptions do not allow verification, and the type material is lost (Table 1).

\section{SYSTEMATIC PALEONTOLOGY}

The higher classification follows De Grave et al. (2009).

Order DECAPODA Latreille, 1802

Infraorder BRACHYURA Linnaeus, 1758

Section DROMIACEA de Haan, 1833

Superfamily HOMOLODROMIOIDEA Alcock, 1900

Family GONIODROMITIDAE Beurlen, 1932 (=

PITHONOTINAE Glaessner, 1933)

Genus EODROMITES Patrulius, 1959

1835 Prosopon von Meyer (pars).

1865 Ogydromites Milne Edwards.

Diagnosis. (after Schweitzer and Feldmann, 2008, amended) Carapace longer to almost as long as wide (width is $0.74-0.91$ of the length), widest across the epibranchial region. Rostrum is variously shaped, with incision in the middle, usually narrowing posteriorly. Augenrest is deep, from longer than wide to wider than long (length 0.8-1.75 of width); suborbital margin extending beyond upper orbital margin. Outer orbital spine is present. Projection of orbital margin intercepts longitudinal axis at angle $50-70^{\circ}$. Two symmetric groups of hepatic pits are present on hepatic regions.

Type species. Prosopon grande von Meyer, 1857, by original designation.

Other species included. E. aequilatus (von Meyer, 1857) as Prosopon; E. depressus (von Meyer, 1860) as Prosopon; E. dobrogea (Feldmann, Lazăr and Schweitzer, 2006) as Cycloprosopon; E. guenteri n. sp.; E. hyznyi n. sp.; E. nitidus (Milne Edwards, 1865) as Ogydromites; E. polyphemi (Gemmellaro, 1869) as Prosopon; E. rostratus (von Meyer, 1840) as Prosopon; E. rotundus n. sp. 
Remarks. According to Schweitzer and Feldmann (2008), Eodromites differs from other representatives of the Goniodromidae in having the carapace widest posterior to interception of cervical groove and lateral margin; lateral margins narrowing posteriorly; broad, rounded rostrum and long augenrest. New species described herein add to the characteristics of the genus. Two species $(E$. aequilatus and $E$. hyznyi n. sp.) differ from others in having a narrow rostrum, with the axial groove reaching its anterior border and lateral margins of the carapace parallel or only slightly narrowing posteriorly (Figure 2). Despite these differences they are considered as members of Eodromites as they share with the congeners other characteristic features. These are hepatic pits formed in groups, weakly developed hepatic tubercles and three pairs of symmetric pits localized on the upper orbital margin (I) and on the epibranchial region: II pair next to cervical groove and III pair next to branchio-cardiac groove (Figure 2.1-2). Augenrest is variable in Eodromites but there is continuity in this character change from shorter than wide (length 0.8 of width), with an elevated posterior angle ( $E$. aequilatus) to much longer than wide (length 1.75 of width) with the posterior angle symmetric along horizontal axis of the augenrest $(E$. grandis) (Figure 2.3).

\section{Key to Species of Eodromites:}

Species: E. depressus, E. nitidus, E. polyphemi and $E$. rostratus are included only tentatively, based only on original drawings, as the material had been lost (see Table 3).

Eodromites grandis (von Meyer, 1857)

Figures 2.2-3, 4

1857 Prosopon grande von Meyer; p. 556.

1857 Prosopon grande von Meyer; Quenstedt, pl. 95, figures $41,43-44$.

1860 Prosopon grande von Meyer; von Meyer, p. 2002, pl. 23, figures 1-3.

1889 Prosopon grande von Meyer; Moericke, $p$. 67 , pl. 6, figure 21 .

1895 Prosopon grande von Meyer; Remeš, p. 203, pl. 2, figure 12.

1925 Prosopon grande von Meyer; Van Straelen, p. 365.

1925 Prosopon grande von Meyer; Beurlen, $\mathrm{p}$. 469.

1929 Pithonoton grande (von Meyer); Glaessner, p. 320.
1933 Pithonoton grande (von Meyer); Glaessner, p.180, figure 1.

1951 Pithonoton grande (von Meyer); Withers, p. 175, figures 7-9.

1959 Eodromites grandis (von Meyer); Patrulius, p. 254.

1966 Eodromites grandis (von Meyer); Patrulius, p. 509, pl. 30, figures 10-14.

1980 Pithonoton grande (von Meyer); Morris, $p$. 14.

1988 Pithonoton grande (von Meyer); Wehner, p. 91, pl. 7, figures 1-2.

2000 Pithonoton grande (von Meyer); Müller et al., figure 18E.

2008 Eodromites grandis (von Meyer); Schweitzer and Feldmann, p. 134, pl. 4, figures A-G.

2010 Eodromites grandis (von Meyer); Schweitzer and Feldmann, figure 5.1-3.

2011 Eodromites grandis (von Meyer); Franţescu, p. 283, figure 9.

2012 Eodromites grandis (von Meyer); Klompmaker et al., p. 790, figure 5, table 2.

Diagnosis. (after Klompmaker et al., 2012, amended) Large-sized species (carapace width reaching about $17 \mathrm{~mm}$ ). Carapace is short (width $0.86-0.91$ of the length), convex, strongly narrowing posteriorly. Lateral borders are covered with small spines. The distance from outer orbital spine to cervical groove (AtC) is relatively short (0.28$0.34 x$ RtC length). Rostrum is short, rounded, without incission in the middle. Augenrest is long (1.4$1.5 x$ longer than wide) and symmetric along the horizontal axis. Upper and suborbital margins are smooth. Projection of orbital margin intercepts longitudinal axis at about 55 degree angle. Anterior groove is present. Hepatic tubercles and groups of hepatic pits are faint.

Comparative material. Poland: Polish Jura, Middle Oxfordian: Opoczno: IGPUW C/1/015, Włodowice: IGPUW C/1/081. Upper Oxfordian: Czerkiesy: IGPUW C/1/021, Patrzyków-Garbacze: IGPUW C/1/039, Wapiennik: IGPUW C/1/070.

Austria: Dörfles near Ernstbrunn, Tithonian: 2008z0204/0004.

Additional material. Poland: Bzów: I-F/MP/1621/ 1509/08; I-F/MP/1701/1517/08; I-F/MP/1725/1517/ 08; I-F/MP/2027/1517/08; I-F/MP/2151/1517/08; IF/MP/3526/1533/08; I-F/MP/3604/1533/08. Grabowa: I-F/MP/6366/1619/14, I-F/MP/6367/ 1619/14. Kroczyce: I-F/MP/6368/1619/14. Niegowonice: I-F/MP/369/1497/08; I-F/MP/928/1507/ 
TABLE 3. Key to species: E. depressus, E. nitidus, E. polyphemi and E. rostratus are included only tentatively, based only on original drawings, as the material had been lost.

\begin{tabular}{|c|c|c|}
\hline & Characters & Species \\
\hline $1 a$. & Carapace longer than wide & 2 \\
\hline $1 \mathrm{~b}$. & Carapace as long as wide & 7 \\
\hline 2a. & Augenrest longer than wide & 3 \\
\hline $2 \mathrm{~b}$. & $\begin{array}{l}\text { Augenrest wider than long, with rounded, posterior angle, assymetrical along the horizontal axis } \\
\text { [carapace much longer than wide; lateral borders between outer orbital spine and cervical groove covered } \\
\text { with tubercles; behind cervical groove borders smooth, parallel; rostrum short, narrow, with truncated } \\
\text { edge; projection of orbital margin intercepts longitudinal axis at angle c. } 75^{\circ} \text {; spines on the upper orbital } \\
\text { margin present; hepatic tubercles present; groups of hepatic pits present; three pairs of pits (I-III, compare } \\
\text { Figure 2.1) present] }\end{array}$ & E. aequilatus \\
\hline 3a. & Rostrum incised in the middle & 4 \\
\hline $3 \mathrm{~b}$. & Rostrum without incision & 5 \\
\hline $4 a$. & $\begin{array}{l}\text { Pairs of pits: I-III present [pair of groups of hepatic pits present; lateral borders smoth; hepatic tubercles } \\
\text { weakly visible; augenrest } 1.75 x \text { longer than wide, symmetric along horizontal axis; projection of orbital } \\
\left.\text { margin intercepts longitudinal axis at angle c. } 60^{\circ} \text { (Figure } 2.3\right) \text { ] }\end{array}$ & E. guenteri n. sp. \\
\hline $4 \mathrm{~b}$. & $\begin{array}{l}\text { Pairs of pits I-III absent [only the tip of the mesogastric region is distinct; posterior margin of carapace not } \\
\text { incised, and not surrounded by with a furrow] }\end{array}$ & E. rostratus \\
\hline $5 a$. & Species relatively small (about $4 \mathrm{~mm}$ max. carapace width) & 6 \\
\hline $5 \mathrm{~b}$. & $\begin{array}{l}\text { Species relatively large (about } 17 \mathrm{~mm} \text { max. carapace width) [rostrum short; hepatic tubercles faint; groups } \\
\text { of hepatic pits present; lateral margis of carapace covered with small serrations; augenrest } 1.4-1.5 \mathrm{x} \\
\text { longer than wide, symmetric along the horizontal axis; projection of orbital margin intercepts longitudinal } \\
\text { axis at about } 55 \text { degree angle; pairs of pits: I-III absent (Figure 2)] }\end{array}$ & E. grandis \\
\hline $6 a$. & $\begin{array}{l}\text { Rostrum long, broad; lateral borders of the carapace are smooth; carapace narrowing posteriorly; hepatic } \\
\text { tubercles small; groups of hepatic pits faint; augenrest barely longer than wide (1.1x), subtriangular, } \\
\text { asymmetric along the horizontal axis, with an elevated posterior angle; projection of orbital margin } \\
\text { intercepts longitudinal axis at about } 50 \text { degree angle; pairs of pits I-III absent (Figure } 2 \text { ) }\end{array}$ & E. rotundus $\mathrm{n} . \mathrm{sp}$. \\
\hline $6 \mathrm{~b}$. & $\begin{array}{l}\text { Rostrum long, strongly narrowing anteriorly; lateral borders of the carapace are smooth; carapace only } \\
\text { slightly narrowing posteriorly; hepatic tubercles absent; groups of hepatic pits are faint; augenrest } 1.2 x \\
\text { longer than wide, subtriangular, asymmetric along the horizontal axis; projection of orbital margin } \\
\text { intercepts longitudinal axis at about } 50 \text { degree angle; I pair of pits present (Figure 2) }\end{array}$ & E. hyznyi n. sp. \\
\hline $7 a$. & Carapace strongly narrowing posteriorly & 8 \\
\hline $7 \mathrm{~b}$. & Carapace only slightly narrowing posteriorly & 9 \\
\hline $8 a$. & $\begin{array}{l}\text { Species relatively large (c. } 24 \mathrm{~mm} \text { max. carapace width); augenrest long, projection of orbital margin } \\
\text { intercepts longitudinal axis at about } 50 \text { degree angle; groups of hepatic pits present; cervical and } \\
\text { branchio-cardiac grooves are deep; branchio-cardiac groove reaches the posterior border of the } \\
\text { carapace; pairs of pits I-III absent }\end{array}$ & E. dobrogea \\
\hline $8 \mathrm{~b}$. & $\begin{array}{l}\text { posterior part of the carapace behind the branchio-cardiac groove is very short and narrow; cardiac region } \\
\text { reaching posterior margin of the carapace }\end{array}$ & E. depressus \\
\hline 9a. & $\begin{array}{l}\text { Augenrest perpendicular to longitudinal axis of the carapace; cervical and branchio-cardiac grooves are } \\
\text { equally deep }\end{array}$ & E. polyphemi \\
\hline $9 \mathrm{~b}$. & Cervical groove is deep, branchio-cardiac groove is shallow & E. nitidus \\
\hline
\end{tabular}




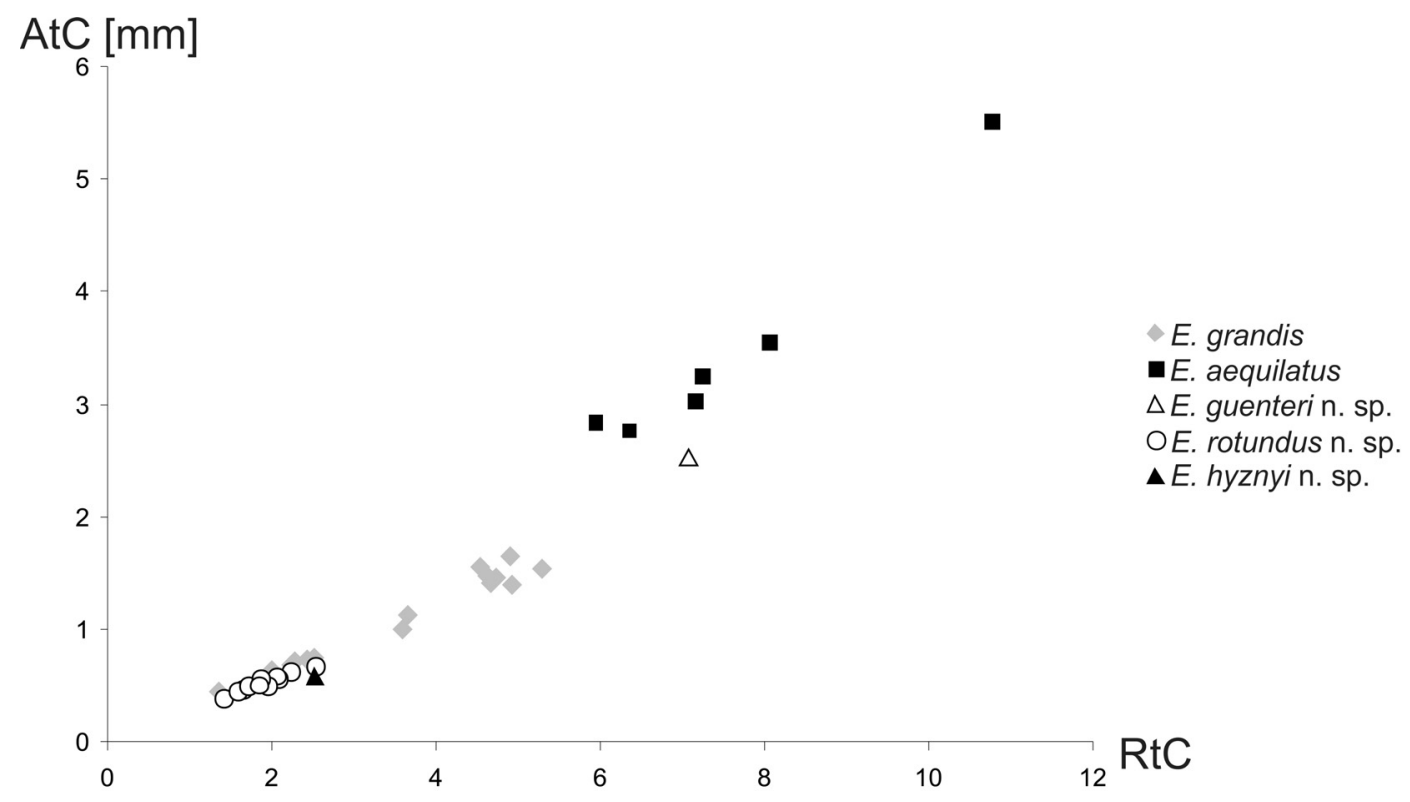

FIGURE 3. Ratio of the AtC and RtC distance in studied species of the genus Eodromites.

08; I-F/MP/3233/1532/08; I-F/MP/4874/1534/08; IF/MP/4927/1534/09; I-F/MP/4999/1543/09; I-F/MP/ 5254/1543/09; I-F/MP/6255/1588/11. Ogrodzieniec: I-F/MP/161/1489/08; I-F/MP/4244/1534/08; IF/MP/6257/1588/11; I-F/MP/6258/1588/11; I-F/MP/ 6259/1588/11. Wysoka: I-F/MP/6369/1619/14.

Dimensions. Carapace width ranges from 2.3 to $8.97 \mathrm{~mm}$, length - from 2.62 to $9.89 \mathrm{~mm}$.

Description of material. The carapace is longer than wide (width $0.86-0.91$ of the length), convex, strongly narrowing posteriorly (Figures 2.2, 4.5). Lateral border of the carapace between outer orbital spine and branchio-cardiac groove is covered with small serrations (Figure 4.3). Outer orbital spine is distinct and sharp. The distance between outer orbital spine and cervical groove (AtC) is $0.28-0.34 \mathrm{x}$ the distance from the anterior border of rostrum to cervical groove (RtC) (Figure 3).

Rostrum is short, rounded, directed downward, without incision. Axial groove is shallow and does not reach the anterior border of rostrum. Rostrum is best preserved in specimens 4874,5254 , 6255 and 6259 (Figure 4.2, 4.5).

Augenrest is long (1.4-1.5x longer than wide), distinctly bordered and deep, symmetric along horizontal axis (Figure 2.3). Upper and suborbital margins are smooth. Suborbital margin extends beyond the upper orbital margin. Anterior groove is present. Projection of orbital margin intercepts longitudinal axis at an angle of ca. 55 degrees. Details of augenrest are best visible in specimens 6255 , 6258 and 6259 (Figures 2.3, 4.8).

Cervical pits are distinct. Hepatic tubercles are faint, best visible in specimen 928 (Figure 4.6). Groups of hepatic pits are shallow, best visible in specimens 2151, 3526, 3604 and 5254 (Figure 4.1). Three pairs of symmetric pits (I-III, Figure 2.1) are absent in this species.

Epigastric regions are rounded. Mesogastric region is bottle-shaped; its borders are better delimited in anterior and posterior part, and very weakly in the middle. There are delicate scars on both sides of a small incision in the middle of posterior border of the mesogastric region. In front of them there is a pair of similar, smaller scars (Figure 4.6, compare also Figure 2.1-2). The urogastric region bears a small tubercle. Cardiac region is flattened, with two tubercles in the anterior, and one tubercle in the posterior part. The epibranchial region is more convex and longer than the branchial region.

Cervical and branchio-cardiac grooves are shallow. Branchio-cardiac groove is deeper in lateral parts (parallel to the cervical groove), its middle part is shallower, almost not visible. Postcervical groove is very shallow, especially in the middle part, deeper laterally and merging with the branchio-cardiac groove.

\section{Eodromites aequilatus (von Meyer, 1857)}

Figures 2, 5 


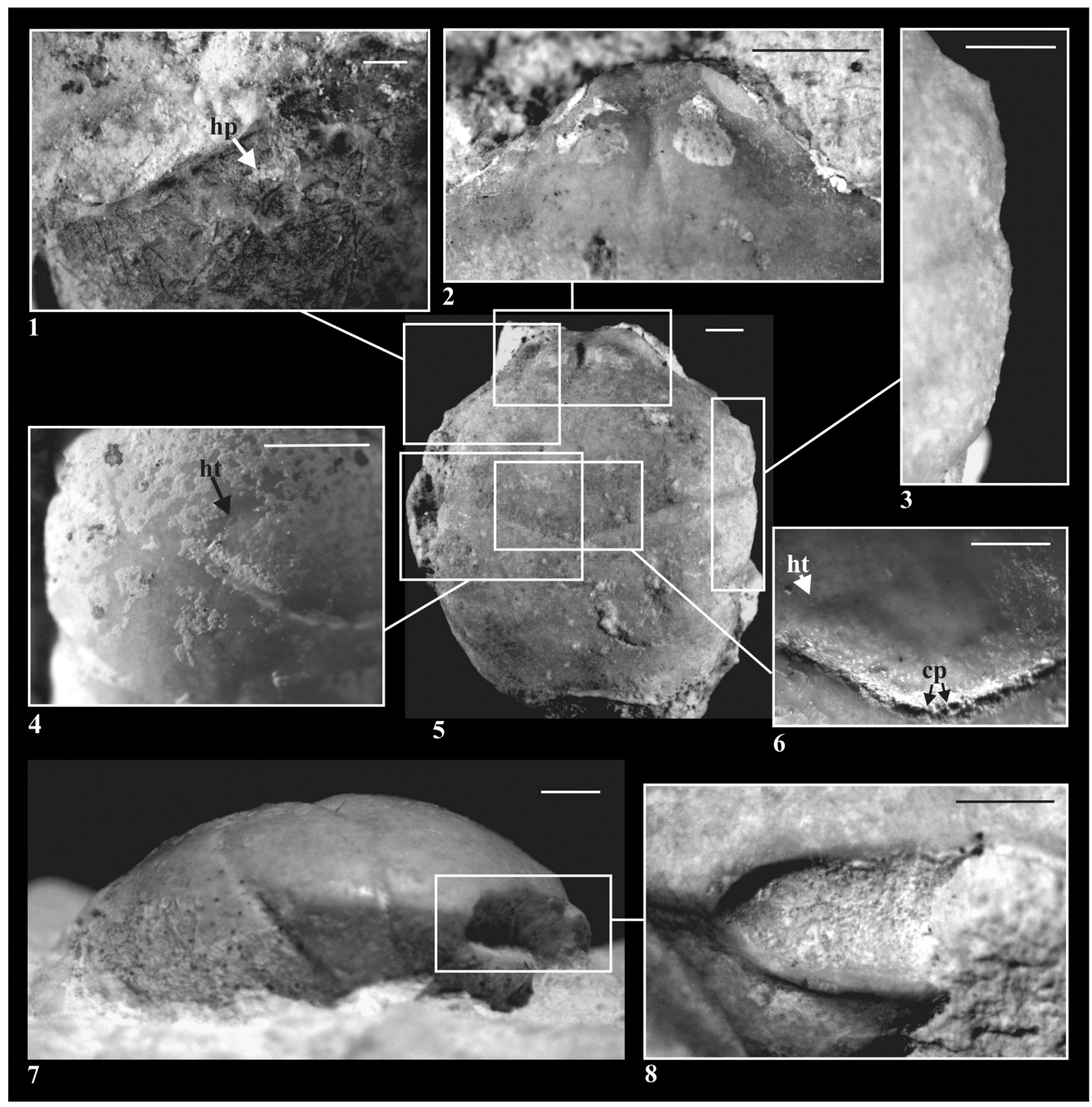

FIGURE 4. Eodromites grandis 1. Groups of hepatic pits (hp) on the hepatic region (3604, Bzów). 2. Rostrum (4874, Niegowonice). 3. Lateral margin covered with serrations (6259, Ogrodzienic). 4. Hepatic tubercles (ht) in the hepatic groove (4244, Ogrodzieniec). 5. Carapace (6259). 6. Mesogastric region, cervical pits (cp), hepatic tubercles (ht) (928, Niegowonice). 7. Lateral view (6255, Niegowonice). 8. Augenrest, anterior view (6259). Scale bars equal $1 \mathrm{~mm}$.

1857 Prosopon aequilatum von Meyer; von Meyer, p. 556.

1860 Prosopon aequilatum von Meyer; von Meyer, p. 194, pl. 23, figure 5.

1929 Pithonoton aequilatum (von Meyer); Glaessner, p. 318.

1985 Pithonoton aequilatum (von Meyer); Collins and Wierzbowski, p. 82, pl. 2, figure 2.
1988 Pithonoton aequilatum (von Meyer); Wehner, p. 74, pl. 5, figures 4-5.

2008 Pithonoton aequilatum (von Meyer); Schweitzer and Feldmann, p. 130, pl. 3, figures E-F.

2010 Pithonoton aequilatum (von Meyer); Schweitzer et al., p. 60. 


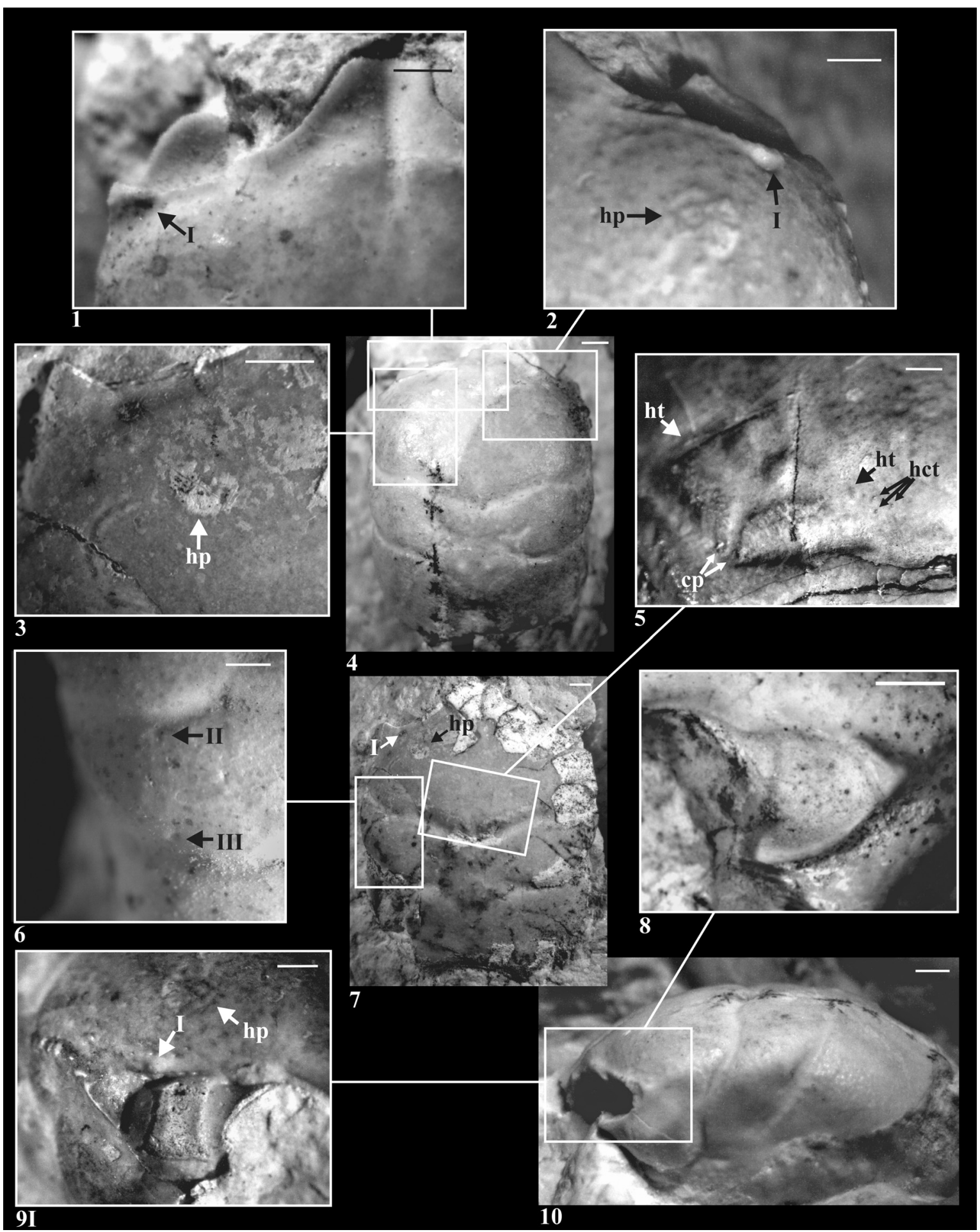

FIGURE 5. Eodromites aequilatus 1. Rostrum and augenrest, dorsal view, pit (I) on the upper orbital margin (IGPUW $\mathrm{C} / 1 / 26$, Antonie). 2. Serrations on the lateral and upper orbital margin, pit on the upper orbital margin (I), groups of hepatic pits (hp) (SMNS70011/2, Stetten). 3. Groups of hepatic pits (hp) (3558). 4. Carapace (IGPUW C/1/11, Holly Cross Mountains). 5. Mesogastric region, cervical pits (cp), hepatic tubercles (ht), tubercles between cardiac and hepatic groove (hct) (SMNS70011/1, Stetten). 6. Pits on the epibranchial region next to cervical groove (II) and branchio-cardiac groove (III) (IGPUW C/1/27, Zalesiaki). 7. Carapace, groups of hepatic pits (hp) on the hepatic region, pit (I) on the upper orbital margin (3558, Bzów). 8. Augenrest, anterior view (IGPUW C/1/26). 9. Augenrest, anterior view (SMNS70011/2). 10. Lateral view (IGPUW C/1/11). Scale bars equal $1 \mathrm{~mm}$. 
2011 Eodromites aequilatus (von Meyer); Schweigert and Koppka, p. 11, figure 9.

Diagnosis. Large sized species (length of the carapace up to $16.52 \mathrm{~mm}$ ), relatively long (length/ width 0.74-0.8). Lateral borders between the outer orbital spine and cervical groove are covered with small spines. Lateral borders behind the cervical groove are smooth. The AtC distance is long (0.420.50 of RtC). Rostrum is short and narrow with a truncated edge. Augenrest is short (length 0.80 of the width), asymmetric along the horizontal axis, with a rounded posterior angle. Upper orbital margin is covered with serrations, the anterior groove is present. Suborbital margin extends beyond upper orbital margin. Projection of orbital margin intercepts longitudinal axis at an angle of ca. 75 degrees. Hepatic tubercles are small. Hepatic pits are arranged in groups. Three pairs of symmetric pits are present: I pair on the upper orbital margin and two pairs on the epibranchial region - II next to cervical groove and III next to the branchio-cardiac groove.

Type material examined. SMNS67336/1 - neotype, SMNS67336/2 - topotype - Braunenberg near Aalen-Wasseralfingen (South-West Germany), Upper Oxfordain, Planula Zone, Galar Subzone.

Comparative material. Germany: SMNS70011/1; SMNS70011/2 - Stetten near Eybach, Lower Kimmergidian, Divisium Zone.

Poland: MWGUW C/1/11 - Holly Cross Mountains, Oxfordian; MWGUW C/1/026 - Antonie (Wieluń Uppland). MWGUW C/1/027 - Zalesiaki (Cracow Jura Chain), Upper Oxfordian, Planula Zone.

Additional material. Poland, Bzów: I-F/MP/3558/ 1533/08.

Dimensions. Length of the largest specimen (SMNS70011/1) is $16.52 \mathrm{~mm}$. The smallest specimen (IGPUWC/1/27) is $7.73 \mathrm{~mm}$ long and $5.92 \mathrm{~mm}$ wide.

Description of material. The carapace is convex, relatively long (width $0.74-0.80$ of the length) (Figures $2,5.4,5.7,5.10)$. Lateral margins between the outer orbital spine and cervical groove are covered with small serrations; behind cervical groove the margins are smooth, parallel. The outer orbital spine is distinct and blunt (Figure 5.1). AtC distance is long (0.42-0.50 of the RtC distance) (Figure 3).

The rostrum is short and narrow, with a truncated edge, slightly directed downwards. An axial groove is very deep, reaching the anterior edge of the rostrum (Figure 5.1). The anterior groove is distinct.
The augenrest is short (length $0.8 \mathrm{x}$ width), bordered and deep, asymmetric along the horizontal axis, with rounded posterior angle. The upper orbital margin is covered with small spines. The suborbital margin extends beyond the upper orbital margin. The projection of orbital margin intercepts longitudinal axis at an angle of ca. 75 degrees. Details of the augenrest are best visible in specimens SMNS70011/1, SMNS70011/2 and MWGUW $\mathrm{C} / 1 / 11$ (Figures 2.3, 5.8-9).

Hepatic tubercles are faint (Figure 5.5). Groups of hepatic pits are distinct (Figures 2.2, 5.2$3,5.7)$. Three pairs of symmetric pits are present: one pair on the upper orbital margin and two pairs on the epibranchial region - II next to cervical groove and III next to branchio-cardiac groove (Figures 2.2, 5.1-2, 5.6, 5.9). Three small tubercles are present between the cervical and the hepatic groove (Figure 5.5).

Epigastric regions are small, rounded. Mesogastric region is bottle shaped, with distinct borders in the anterior and posterior part, weakly marked in the middle. Two delicate scars occur on both sides of a small incision in the middle of posterior border of the mesogastric region. Anteriorly to them there is a pair of similar, smaller scars (best preserved in specimens SMNS70011/1, SMNS70011/2, SMNS67336/1 and SMNS67336/2; Figures $2.2,5.5)$. An easily visible tubercle is present on the urogastric region. Cardiac region is convex, distinct, with two tubercles in the anterior part and one in the posterior part.

The epibranchial region is more convex and much shorter than the branchial region.

The cervical groove is deep; the branchio-cardiac groove is deep in lateral parts (parallel to cervical groove); its middle part is shallower, but also distinctly visible. The postcervical groove is deeper in lateral parts, shallower in the middle and merges with the branchio-cardiac groove.

\section{Eodromites rotundus n. sp.}

Figures 2.2-3, 6

zoobank.org/586226D0-4C19-450E-BC3E-5F37594ECF7C

Diagnosis. Small sized species (max. carapace length about $4 \mathrm{~mm}$ ). Carapace is longer than wide (width $0.80-0.88$ of length). Lateral borders are smooth, narowing posteriorly. Outer orbital spine is distinct. The AtC distance is very short (0.26-0.30x RtC distance). Rostrum is long and wide, rounded. Augenrest is barely longer than wide $(1.1 \mathrm{x})$, bordered, deep, subtriangular, asymmetric along the horizontal axis, with elevated posterior angle. Projection of orbital margin intercepts longitudinal axis at about a 50 degree angle. Hepatic tubercles are 


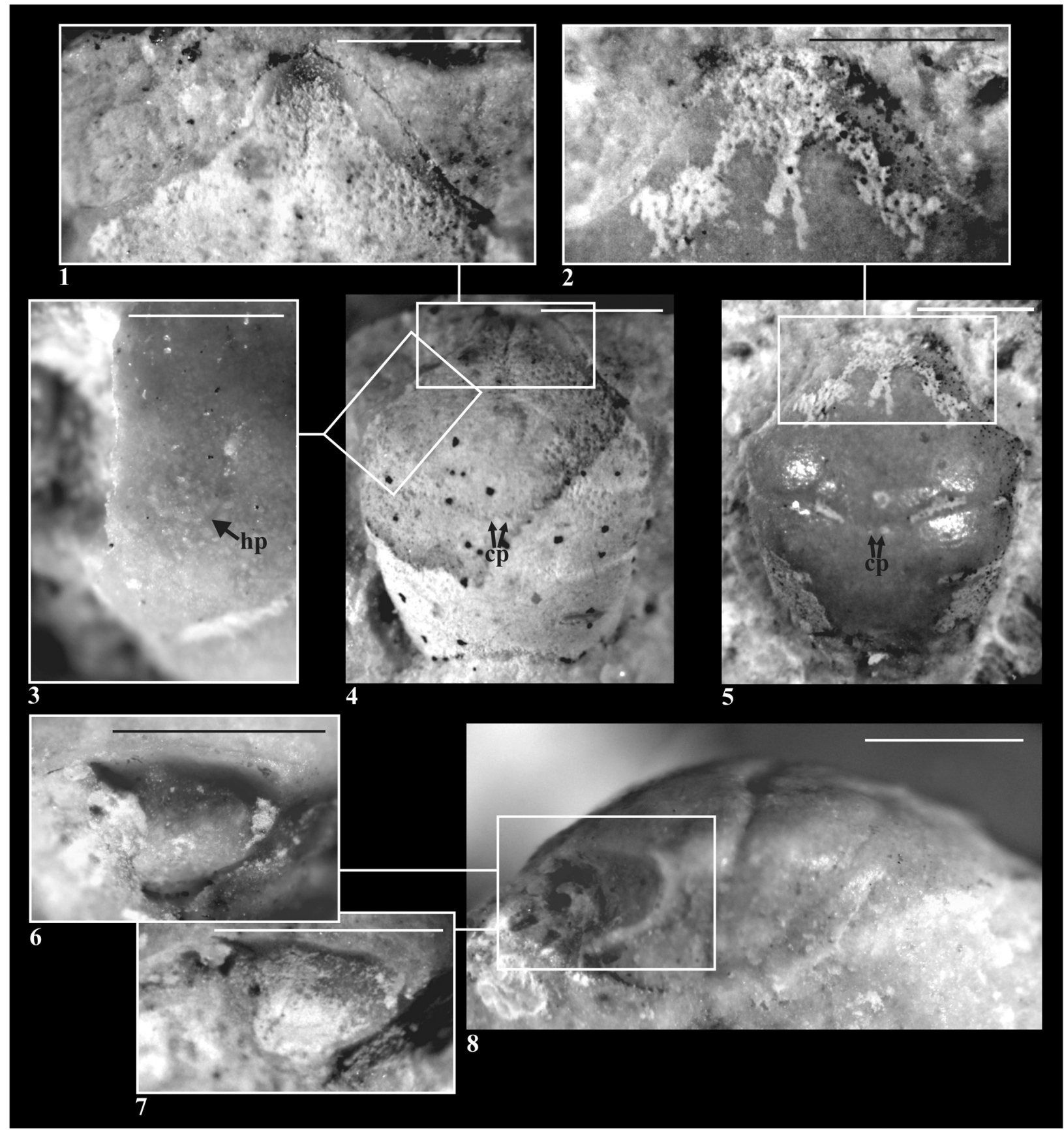

FIGURE 6. Eodromites rotundus n. sp. 1. Paratype, rostrum - dorsal view (3992, Ogrodzieniec). 2. Paratype, rostrum - dorsal view (6270, Ogrodzieniec). 3. Groups of hepatic pits (hp) on the hepatic region (2237, Bzów). 4. Carapace - paratype, cervical pits (cp) (3992). 5. Carapace - paratype, cervical pits (6270). 6. Augenrest, anterior view (619, Ogrodzieniec). 7. Holotype - augenrest, anterior view (6271, Ogrodzieniec). 8. Holotype, lateral view (6271). Scale bars equal $1 \mathrm{~mm}$.

faint. Hepatic pits are arranged in groups. Three pairs of symmetric pits on the upper orbital margin and on the epibranchial region are absent. Epibranchial region is much shorter than the branchial region.
Etymology. A new species name derives from a Latin word "rotundus" - rounded. It refers to rounded rostrum, characteristic to that species.

Type material. Holotype: I-F/MP/6271/1599/12, type locality: Ogrodzieniec, age: Lower and Middle Oxfordian. 
Paratypes. I-F/MP/3992/1533/08; I-F/MP/6270/ 1599/12, locality: Ogrodzieniec, age as for the holotype; I-F/MP/1842/1517/08, locality: Bzów, age: Middle Oxfordian.

Additional material. Poland, Bzów: I-F/MP/1677/ 1517/08; I-F/MP/2237/1528/08; I-F/MP/2509/1528/ 08; I-F/MP/6370/1619/14. Niegowonice: I-F/MP/ 193/1495/08. Ogrodzieniec: I-F/MP/619/1502/08; IF/MP/663/1502/08; I-F/MP/685/1502/08; I-F/MP/ 4061/1533/08; I-F/MP/4165/1533/08; I-F/MP/4287/ 1534/08; I-F/MP/6274/1599/12.

Dimensions. The biggest specimen (663) is 3.81 $\mathrm{mm}$ long and $3.35 \mathrm{~mm}$ wide, the smallest (685) is $1.92 \mathrm{~mm}$ wide.

Description of material. The carapace is convex, longer than wide (width $0.80-0.88$ of the length); especially elongated is the anterior part of the carapace. Lateral borders are smooth, narrowing posteriorly. The outer orbital spine is distinct and sharp. The AtC distance is very short $(0.26-0.30$ of the RtC distance) (Figures 2.2, 3).

The rostrum is long and broad, rounded, directed downwards. Axial groove is deep, not reaching the anterior margin of rostrum (Figure 6.1-2).

The augenrest is only slightly longer than wide (1.1x), bordered and deep, subtriangular, ansymmetric along the horizontal axis, with an elevated posterior angle. The anterior groove is absent. The suborbital margin extends beyond the upper orbital margin. Projection of an orbital margin intercepts the longitudinal axis at about a 50 degree angle (Figures 2.3, 6.6-7).

Hepatic tubercles and pits are very faint. Groups of hepatic pits are best visible in specimens 663, 1842 and 6270 (Figure 6.3).

Epigastric regions are small. Mesogastric region is bottle shaped, rather poorly delimited. Two delicate scars on both sides of a small incision in the middle of posterior border of the mesogastric region are less visible here than in other studied species. The urogastric region bears a small tubercle. The cardiac region is slightly convex, with two tubercles in its anterior and one in the posterior part.

The epibranchial region is more convex than the branchial region but the difference is not as conspicuous as in E. grandis. The branchial region is much longer than the epibranchial region (Figures 2.2, 6.4-5).

The cervical groove is deeper than the branchio-cardiac groove, which is very faint in the middle part. Postcervical groove is also poorly visible.
Remarks. Structures like hepatic tubercles, groups of hepatic pits, epigastric regions or mesogastric region are weakly visible in this small species, but present and recognizable under the sidelight.

The carapace of $E$. rotundus $\mathrm{n}$. sp. is narrowing posteriorly as in $E$. grandis, but it is relatively longer. It is shorter and much smaller than $E$. aequilatus. Eodromites rotundus $\mathrm{n}$. $\mathrm{sp}$. has the lateral borders smooth, unlike both these species compared. Also the AtC distance is shortest in $E$. rotundus. The rostrum is longer than in $E$. grandis and broader than in $E$. aequilatus. The augenrest is shorter than in $E$. grandis but longer than in $E$. aequilatus, with a similarly elevated posterior angle. The hepatic tubercles are faint as in other species. The groups of hepatic pits are weaker than in E. grandis and E. aequilatus. Epibranchial region of $E$. rotundus $\mathrm{n}$. sp. is more convex than the branchial region but the difference is not as conspicuous as in E. grandis.

\section{Eodromites hyznyi $\mathrm{n} . \mathrm{sp}$. \\ Figures 2.2-3, 7}

zoobank.org/204234B5-E279-4476-884C-1EC06D90B25B

Diagnosis. Small sized species (width about 3 $\mathrm{mm}$ ), carapace is longer than wide. Lateral borders are almost parallel, smooth. AtC distance is very short (0.23x the RtC distance). Rostrum is long, strongly narrowing anteriorly. Augenrest is short (1.2x longer than wide), bordered, subtriangular and asymmetric along the horizontal axis, with elevated posterior angle. Upper and suborbital margins are smooth. Projection of orbital margin intercepts longitudinal axis at about a 50 degree angle. Hepatic tubercles are absent. Groups of hepatic pits are shallow and faint. There is only one of three pairs of symmetric pits present, a very shallow I pair on the upper orbital margin. There are two shallow grooves running parallel to lateral sections of the branchio-cardiac groove.

Etymology. Species' name is dedicated to Matúš Hyžný, a specialist of fossil decapods.

Type material. Poland: Holotype: I-F/MP/4973/ 1543/09, type locality: Niegowonice, age: Middle to Upper Oxfordian (upper Elisabethae Subzone to the upper Wartae Subzone).

Paratypes. I-F/MP/1067/1508/08, locality: Niegowonice, age as the holotype; I-F/MP/3468/1533/ 08, locality: Bzów, age: Middle Oxfordian (Transversarium Zone).

Additional material. Niegowonice: I-F/MP/4558/ 1534/08; I-F/MP/5062/1543/09.

Dimensions. Width of carapace ranges from 2.72 $\mathrm{mm}$ to $3.39 \mathrm{~mm}$. A total length of carapace cannot 


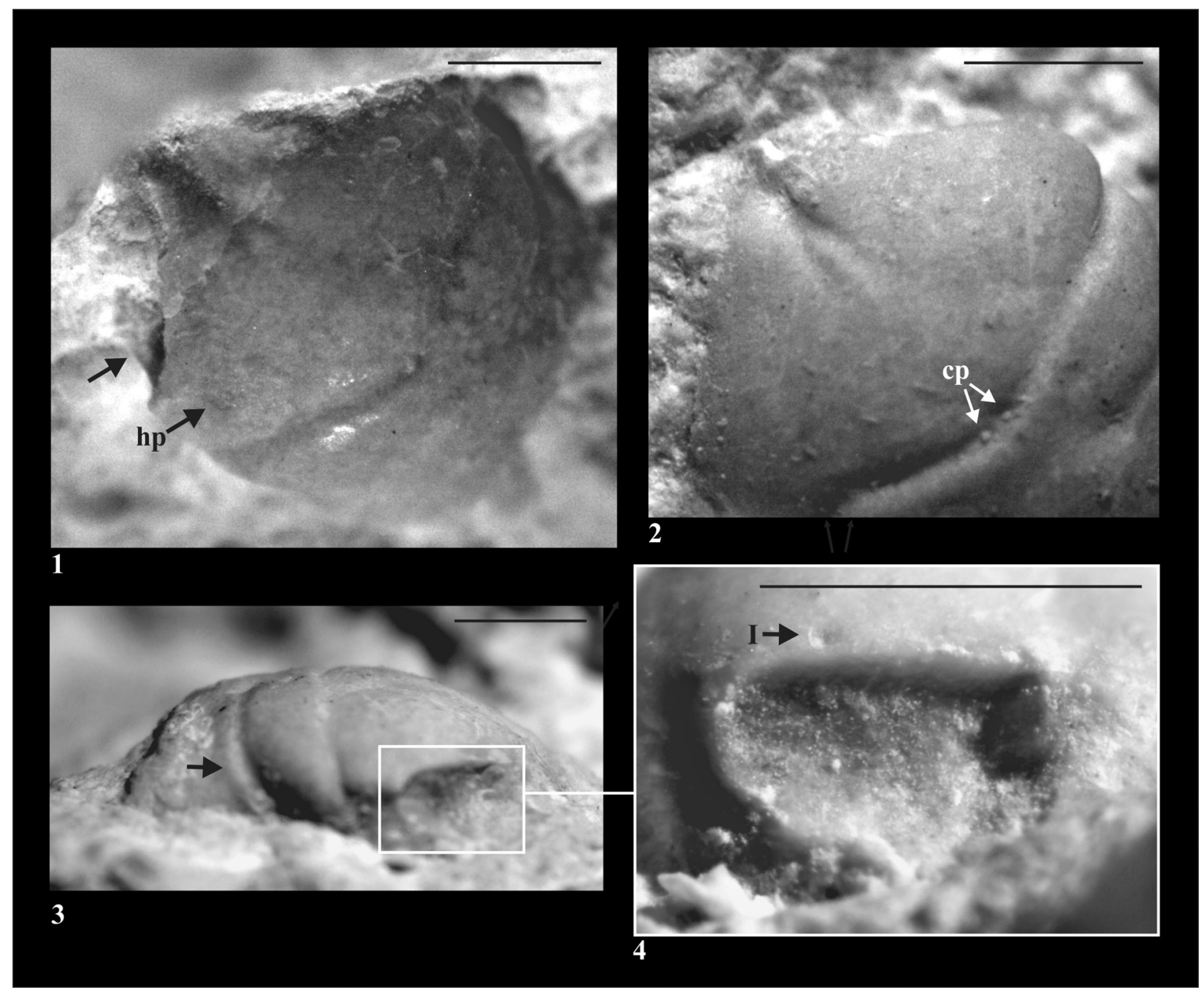

FIGURE 7. Eodromites hyznyi n. sp. 1. Holotype, suborbital margin marked with an arrow (4973, Niegowonice). 2. Paratype, cervical pits (cp) (3468, Bzów). 3. Paratype, lateral view, groove parallel to branchio-cardiac groove marked with an arrow (3468). 4. Paratype, augenrest, I - pit on the upper orbital margin (3468). Scale bars equal $1 \mathrm{~mm}$.

be defined precisely because posterior border of the carapace is not preserved in any specimen.

Description of material. The carapace is longer than wide, flattened. Lateral borders are smooth, slightly narrowing posteriorly. Outer orbital spine is present. The AtC distance is small ( 0.23 of the RtC distance) (Figures 2.2, 3).

The rostrum is long, strongly narrowing anteriorly, sharply ended. The axial groove is deep, reaching to the anterior edge of rostrum. The rostrum is best preserved in specimen 4973 (Figure 7.1). The anterior groove is absent.

The augenrest is longer than wide (length 1.2 of the width), asymmetric along the horizontal axis, with an elevated posterior angle. Upper and suborbital margins are smooth; suborbital margin extends beyond the upper orbital margin. The pro- jection of orbital margin intercepts longitudinal axis at about a 50 degree angle. Details of augenrest are best visible in specimens 1067, 3468 and 4973 (Figures 2.3, 7.4).

Epigastric regions are rounded, flattened. The mesogastric region is bottle-shaped, with distinct border in anterior and posterior part, and faint in the middle. There are two delicate scars on both sides of a small incision in the middle of posterior border of this region. In front of them there is a pair of similar, smaller scars. The urogastric region bears a small, indistinct tubercle.

The cervical pits are rounded (Figure 7.2). Hepatic tubercles are absent. Groups of hepatic pits are very faint, best visible in specimen 1067. There is only one of the three pairs of symmetric 
pits present, a very shallow I pair on the upper orbital margin (Figure 7.4).

The cardiac region is flattened, with two tubercles in its anterior part and one in the posterior part. The epibranchial region is more convex and much shorter than branchial region.

The cervical groove is deep. The branchiocardiac groove is deep in lateral parts (parallel to cervical groove), and very faint in the medial part. There are two shallow grooves running parallel to the lateral sections of the branchio-cardiac groove (Figure 7.3). The postcervical groove is deeper in lateral parts, shallower in the middle; it merges with the branchio-cardiac groove.

Remarks. The carapace of Eodromites hyznyi n. $\mathrm{sp}$. is relatively longer and less narrowing posteriorly than in E. grandis. Lateral borders are smooth in contrast to $E$. grandis and $E$. aequilatus. The AtC distance is relatively shorter than in other three species. Rostrum is here relatively longest, and narrow as in $E$. aequilatus. The augenrest is longer than in $E$. aequilatus and $E$. rotundus n. sp., and shorter than in E. grandis. The groups of hepatic pits are not as well visible as in other mentioned species. In contrast to other species, the hepatic tubercles are absent.

\section{Eodromites guenteri n. sp.}

Figures 2.2-3, 8

\section{zoobank.org/8E719474-23ED-4C8B-9DA4-226DB961B870}

Diagnosis. Large-sized species (length of the holotype $11.96 \mathrm{~mm}$ ), longer than wide (width $0.88 x$ length). Lateral borders are smooth. AtC distance is long $(0.37 x \mathrm{RtC})$. Rostrum is short and rounded, with an incision in the middle. Augenrest is very long (1.75x longer than wide), symmetric along the horizontal axis. Projection of orbital margin intercepts longitudinal axis at about a 60 degree angle. Anterior groove is very faint. Hepatic tubercles are faint; groups of hepatic pits are well visible. Three pairs of symmetric pits; I-III are present. There are two tubercles between the cervical and hepatic groove.

Etymology. Species' name is dedicated to Günter Schweigert (Staatliches Museum für Naturkunde, Stuttgart, Germany), a world-known palaeontologist and a specialist of fossil decapods.

Type material. Holotype: SMNS61668/4. Type locality: Blaubeuren, Sonderbucher Steige, Massenkalk formation (Germany). Age: Upper Kimmeridgian, Eudoxus Zone.

Dimensions. Length of the holotype is $11.96 \mathrm{~mm}$, width is $10.57 \mathrm{~mm}$.

Description of material. The carapace is moderately flattened, relatively long (width 0.88 of the length). Lateral margins are smooth, narrowing posteriorly. The outer orbital spine is distinct and sharp. The AtC distance is longer than in E. grandis but shorter than in $E$. aequilatus ( 0.37 of the RtC distance) (Figures 2.2, 3).

The rostrum is short and rounded, narrower than in E. grandis, slightly directed downwards, with an incision in the middle. An axial groove is very shallow, not reaching the anterior margin of rostrum (Figure 8.1).

The augenrest is longer than in other studied species (1.75x longer than wide), bordered, and symmetric along the horizontal axis. The upper and suborbital margins are not well preserved; the suborbital margin extends beyond the upper orbital margin (Figures 2.3, 8.7). An anterior groove is very faint. A projection of orbital margin intercepts the longitudinal axis at about 60 degree angle.

Cervical pits are rounded, distinct; hepatic tubercles are faint. Three pairs of symmetric pits are present: one pair on the upper orbital margin and two pairs on the epibranchial region, II next to the cervical groove and III next to the branchio-cardiac groove. There are two tubercles between the cervical and the hepatic groove (Figures 2.2, 8.1, 8.3).

Epigastric regions are small, rounded. Mesogastric region is bottle shaped; only its posterior margin is well visible. There are delicate scars on both sides of a small incision in the middle of posterior border of the mesogastric region; and in front of them a pair of nodular, smaller scars is present. The urogastric region bears a small, indistinct tubercle (Figure 8.2, 8.6). The cardiac region is slightly flattened, with two tubercles in its anterior and one in the posterior part.

The epibranchial region is flattened as the branchial region and also short.

The cervical and branchio-cardiac grooves are deep in lateral parts and shallower in medial parts. The branchio-cardiac groove is almost not visible posteriorly to the cardiac region. The postcervical groove is weakly visible, deeper in lateral parts; it merges with the branchio-cardiac groove.

Remarks. The species most similar to E. guenteri $\mathrm{n}$. sp. is E. grandis, which differs in the AtC distance being shorter and in the absence of pits I-III. In contrast to other congeners, E. guenteri n. sp. has rostrum incised in the middle. This species has also the longest augenrest of all studied species. The groups of hepatic pits are weaker than in $E$. aequilatus but more distinct than in remaining species. 


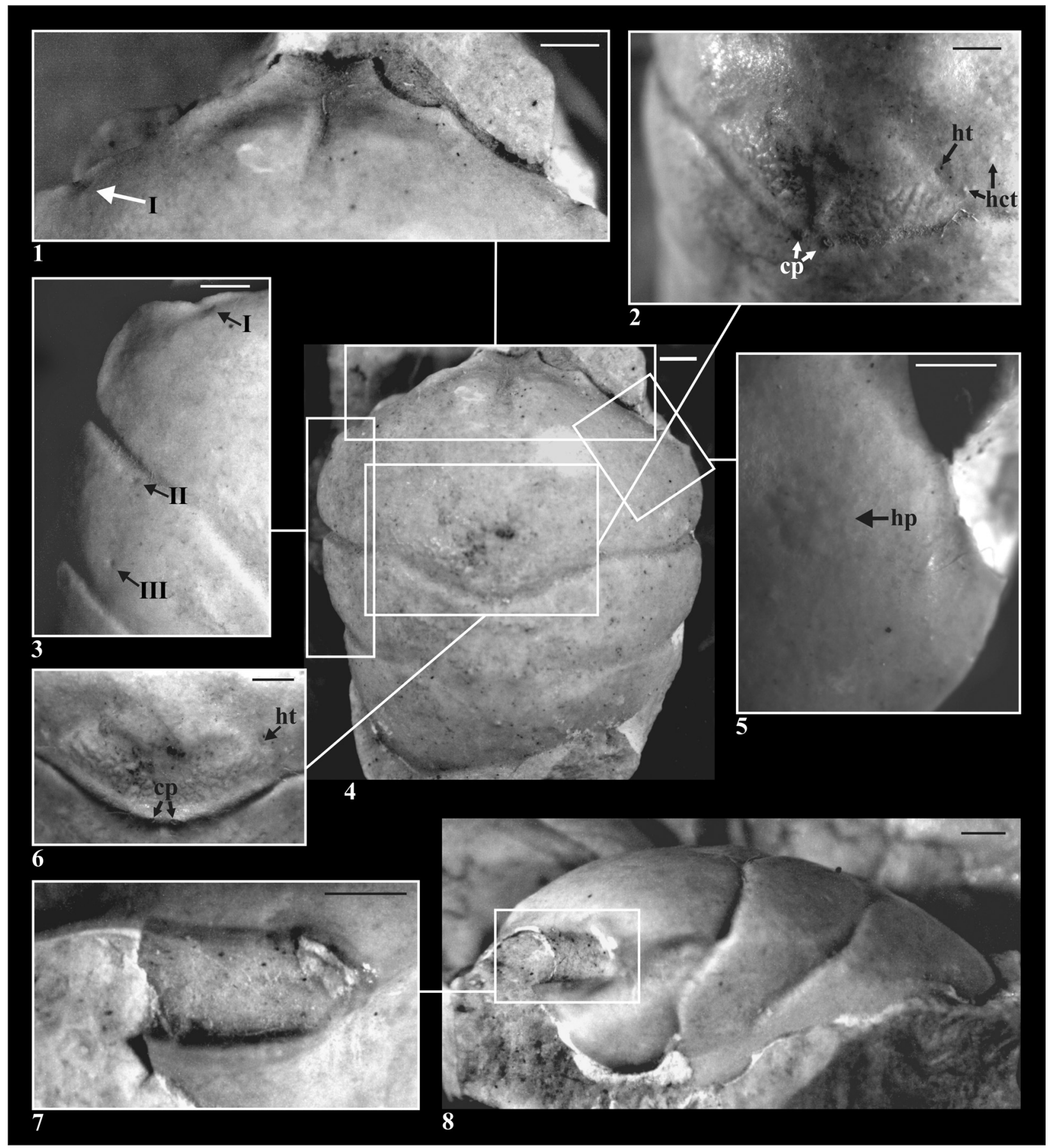

FIGURE 8. Eodromites guenteri n. sp., holotype 1. Rostrum, dorsal view, pit on the upper orbital margin (I) (SMNS61668/4, Blaubeuren). 2. Mesogastric region, cervical pits (cp), hepatic tubercles (ht), tubercles between cervical and hepatic groove (hct). 3. Pits: I - on the upper orbital margin, on the epibranchial region next to the cervical groove (II) and the branchio-cardiac groove (III). 4. Carapace. 5. Groups of hepatic pits on the hepatic region (hp). 6. Mesogastric region, cervical pits (cp), hepatic tubercles (ht). 7. Augenrest, anterior view. 8. Carapace, lateral view. Scale bars equal $1 \mathrm{~mm}$. 


\section{DISCUSSION}

The species included hitherto in Eodromites share the following features: carapace strongly narrowed posteriorly, augenrest concave, long and symmetric, and rostrum broad and rounded, without anterior incision. Some of these characteristics differ in Eodromites aequilatus transferred to Eodromites in 2011 (Schweigert and Koppka, 2011) and in the two new species described herein. Lateral borders of the carapace of Eodromites aequilatus are parallel to each other. Also the carapace of $E$. hyznyi $\mathrm{n}$. sp. is only slightly narrowing. Augenrests of $E$. aequilatus and $E$. rotundus are very short. Rostra of $E$. aequilatus and $E$. hyznyi $\mathrm{n}$. sp. are also divergent from other congeners: in $E$. aequilatus the rostrum is short and narrow with a truncated edge, in E. hyznyi n. sp. it is longer, narrowing anteriorly and sharply ended. Features described above (parallel lateral borders, short augenrest and narrow rostrum) and below suggest close relationship with Tanidromites and all Tanidromitidae and confirm earlier suppositions of Schweigert and Koppka (2011).

The new diagnostic features proposed herein in Eodromites include: groups of hepatic pits, hepatic tubercles, and three pairs of symmetric pits. These characters are stable in the species of the genus with known type material, and could be confirmed on photographs of specimens published earlier. Moreover, their pattern characteristic to the species is recognizable in specimens of all sizes, including the smallest ones. Admittedly, they are more distinct on carapaces of larger species like $E$. grandis, E. aequilatus, E. dobrogea or E. guenteri n. sp., but also visible on smaller species like $E$. hyznyi n. sp. or E. rotundus n. sp.

Groups of hepatic pits present a new character of the genus. Previously in this position only single pits were described in the Tanidromitidae (Schweigert and Koppka, 2011; Starzyk, 2013). The perseverance of these structures on carapaces of Eodromites indicates their importance to the crabs of this genus. They might be the traces of sensory setae gathered in groups, while single pores in Tanidromites suggest traces of single setae.

Similar groups of hepatic pits can be observed also on photographs of Cycloprosopon (Goniodromitidae) (Schweitzer and Feldmann, 2010, figures $2.1,3-4,4.6)$ and evidence a close relationship of these two genera. They share more similarities, which will be treated in a separate paper. Main differences between these genera are: a very short carapace of Cycloprosopon in octagonal shape, a very shallow branchio-cardiac groove, a flattened subhepatic region, an augenrest with suborbital margin not extending beyond upper orbital margin and a narrow posterior margin.

Three pairs of symmetric pits (Figure 2.1) were not found earlier in the two other related genera, Tanidromites and Goniodromites, and appear only in a few species of Eodromites. Interestingly, Eodromites aequilatus, although most divergent from other congeners (differences in the shape of the rostrum, augenrest and overall shape of the carapace), still shares the presence of these pits with $E$. guenteri n. sp., which is very similar to $E$. grandis, a type species.

After studies on species of Eodromites some trends began to be apparent. Eodromites aequilatus is most similar to the species of Tanidromites in shape of the carapace and also by the augenrest being relatively short, with an elevated posterior angle and asymmetric along the horizontal axis of the augenrest. The main difference is its depth; the augenrest in Tanidromites is flat, whilst in Eodromites it is deep (concave). In E. rotundus $\mathrm{n}$. sp. and $E$. hyznyi n. sp. the augenrest is also short, with an elevated posterior angle. E. guenteri n. sp. and $E$. grandis have much longer and symmetric augenrests, which makes them similar to Goniodromites.

Small structures of the carapace described above plausibly were essential for biology of these crabs, as all interactions between the crab's organism and the environment take place through stuctures localized on the cuticle. These structures are highly variable in shape and size, ranging from large teeth on chelipeds to minuscule ornaments (Garm, 2004). They might also correspond to attachments of the muscles (Crônier and Boursicot, 2009; Kato et al., 2010; Ng et al., 2008; Schweigert and Koppka, 2011; Schweitzer and Feldmann, 2009; Starzyk, 2013).

These structures are great characters distinguishing species of Eodromites, as the presence or absence of particular pits or tubercles can be clearly determined on the carapaces with or without the cuticle.

\section{ACKNOWLEDGEMENTS}

I am particularly grateful to G. Schweigert for giving me a hearty welcome in the Staatliches Museum für Naturkunde in Stuttgart. I thank E. Krzemińska for all the help and advice. I also thank the reviewers: M. Hyžný and F. Vega for their work and helpful leads. This project was supported by the grant No. N N303 811940 of the Polish Ministry 
of Science and Education to N. Starzyk and E. Krzemińska.

\section{REFERENCES}

Alcock, A. 1900. Materials for a carcinological fauna of India. No. 5. The Brachyura Primigenia, or Dromiacea. Journal of the Asiatic Society of Bengal, 68 (2):123-169.

Beurlen, K. 1925. Über Brachyuren- und Anomurenreste des Schwäbischen Jura. Neues Jahrbuch für Mineralogie, Abteilung B, Beilageband, 52:464-532.

Beurlen, K. 1932. Brachyurenreste aus dem Lias von Bornholm mit Beiträgen zur Phylogenie und Systematik der Brachyuren Dekapoden. Paläontologische Zeitschrift, 14:52-66.

Collins, J.S.H. and Wierzbowski, A. 1985. Crabs from the Oxfordian sponge megafacies of Poland. Acta Geologica Polonica, 35(1-2):73-88.

Crônier, C. and Boursicot, P.Y. 2009. A new decapod crustacean faunule from the Middle Jurassic of northwest France. Palaeontology, 52(6):1275-1289.

de Haan, W. 1833-1850. Crustacea. In de Siebold, P.F. (ed.), Fauna Japonica sive Descriptio Animalium, quae in Itinere per Japoniam, Jussu et Auspiciis Superiorum, qui Summum in India Batava Imperium Tenent, Suscepto, Annis $1823-1830$ Collegit, Notis, Observationibus et Adumbrationibus Illustravit. J. Müller et Co., Lugduni-Batavorum (=Leiden). i-xvii, ixxxi, ix-xvi.

De Grave, S., Pentcheff, N.D., Ahyong, S.T., Chan, T.Y., Crandall, K.A., Dworschak, P.C., Felder, D.L., Feldmann, R.M., Fransen, C.H.J.M., Goulding, L.Y.D., Lemaitre, R., Low, M.L., Martin, J.W., Ng, P.K.L., Schweitzer, C.E., Tan, S.H., Tshudy, D. and Wetzer, R. 2009. A classification of recent and fossil genera of decapod crustaceans. The Raffles Bulletin of Zoology Supplement, 21:1-109.

Dorn, P. 1930. Die Ammonitenfauna des untersten Malm der Frankenalb. I. Die Perisphinctiden. Palaeontographica, 73:107-172.

Feldmann, R.M., Lazăr, I. and Schweitzer, C. 2006. New crabs (Decapoda: Brachyura: Prosopidae) from Jurassic (Oxfordian) sponge bioherms of Dobrogea, Romania. Bulletin of the Mizunami Fossil Museum, 33:1-20.

Fraaije, R.H.B., Krzemiński, W., Van Bakel, B.W.M., Krzemińska, E. and Jagt, J.W.M. 2012a. The earliest record of pylochelid hermit crabs from the Late Jurassic of southern Poland, with notes on paguroid carapace terminology. Acta Palaeontologica Polonica, 57:647-654.

Fraaije, R.H.B., Krzemiński, W., Van Bakel, B.W.M., Krzemińska, E. and Jagt, J.W.M. 2012b. The sixth abdominal tergites of paguroid anomurans - a newly recognized crustacean macrofossil type. Neues Jahrbuch für Geologie und Paläontologie -Abhandlungen, 266:115-122.
Fraaije, R.H.B., Krzemiński, W., Van Bakel, B.W.M., Krzemińska, E. and Jagt, J.W.M. 2012c. New Late Jurassic symmetric hermit crabs from the southern Polish Uplands and early paguroid diversification. Acta Palaeontologica Polonica, http://dx.doi.org/ 10.4202/ app. 2012.022.

Franţescu, O.D. 2011. Brachyuran decapods (including five new species and one new genus) from Jurassic (Oxfordian - Kimeridgian) coral reef limestones from Dobrogea, Romania. Neues Jahrbuch für Geologie und Paläontologie - Abhandlungen, 259:271-297.

Garm, A. 2004. Revising the definition of the crustacean seta and setal classification systems based on examinations of the mouthpart setae of seven species of decapods. Zoological Journal of the Linnean Society, 2004, 142:233-252.

Gemmellaro, G.G. 1869. Studi paleontologici sulla fauna del calcare a Terabratula janitor del Nord si Sicilia. Palermo, 1:11-18.

Glaessner, M.F. 1929. Crustacea Decapoda. In Pompeckj, J.F. (ed.), Fossilium Catalogus: Animalia, pars 41:1-464; Berlin.

Glaessner, M.F. 1933. Die Krabben der Juraformation. Centralblatt für Mineralogie, Geologie und Paläontologie, Abteilung B, 3:178-191.

Kato, H., Takahashi, T. and Taira, M. 2010. Late Jurassic Decapod Crustaceans from Northeast Japan. Paleontology, 53(4):761-770.

Klompmaker, A.A., Feldmann, R.M. and Schweitzer, C.E. 2012. A Hotspot for Cretaceous Goniodromitids (Decapoda: Brachyura) from Reef Associated Strata in Spain. Journal of Crustacean Biology, 32(5):780801.

Klompmaker, A.A., Hyžný, M. and Jakobsen, S.L. 2015. Taphonomy of decapod crustacean cuticle and its effect on the appearance as exemplified 1 by new and known taxa from the Cretaceous-Danian crab Caloxanthus. Cretaceous Research, 55:141-151.

Krzemińska, E., Krzemińnski, W., Fraaije, R.H.B., van Bakel, B.W.M. and Jagt, J.W.M. 2015. Allometric ontogenetic changes in two Late Jurassic gastrodorid hermit crabs (Crustacea, Decapoda, Anomura) from central Europe. Journal of Systematic Palaeontology, http://dx.doi.org/10.1080/14772019.2015.1018968.

Latreille, P.A. 1802-1803. Histoire naturelle, générale et particuliére, des crustacés et des insects, Paris.

Linnaeus, C.V. 1758. Systema naturae per regna tria naturae, secundum classes, ordines, genera, species, cum characteribus, differentiis, synonymis, locis. Ed. Decimal, reformata. I, Regnum animale. Stockholm (Laurentii Slavii).

Lörenthey, E. and Beurlen, K. 1929. Die fossilen Dekapoden der Länder der Ungarischen Krone. Geologica Hungarica, Series Palaeontologica, 3:1-421.

Milne Edwards, A. 1865. Note sur deux nouveaux crustacés fossiles du terrain néocomien du Département de L'Yonne. Bulletin de la Société des Sciences Historiques et Naturelles de l'Yonne, 19:341-347. 
Moericke, W. 1889. Die Crusteceen der Stramberger Schichten. Palaeontographica, Sechste Abtheilung, 2:43-72.

Morris, S.F. 1980. Catalogue of the type and figured specimens of fossil Crustacea (Excel. Ostracoda), Chelicerata, Myriapoda and Pycnogonida in the British Museum (Natura History). London (Trustees of the British Museum, Natura History).

Müller, P., Krobicki, M. and Wehner, G. 2000. Jurassic and Cretaceous primitive crabs of the family Prosopidae (Decapoda: Brachyura) - their taxonomy, ecology and biogeography. Annales Societalis Poloniae, 70:49-79.

Ng, P.K.L., Guinot, D. and Davie, P.J.F. 2008. Systema Brachyurorum: Part I. An annotated checklist of extant brachyuran crabs of the world. The Raffles Bulletin of Zoology, 17:1-286.

Patrulius, D. 1959. Contribution à la systématique des Décapodes néojurassiques. Revue de Géologie et Géographie, 3:249-257.

Patrulius, D. 1966. Decapoda dolnego tytonu z Woźnik (Polskie Karpaty Zachodnie). Rocznik Polskiego Towarzystwa Geologicznego, 36(1):495-519.

Quenstedt, F.A. 1856-1858. Der Jura. Tübingen (Verlag der H. Lauppschen Buchhaldung).

Remeš, M. 1895. Beiträge zur Kenntnis der Crustaceen der Stramberger Schichten. Bulletin International de l'Académie des Sciences de Bohème, 2:200-204.

Reuss, A.E. 1858. Über kurzschwänzige Krebse im Jurakalke Mährens. Stizungsberichte der Kaiserlichen Akademie der Wissenschaften. MathematischNaturwissenschaftliche Classe, 31:5-13.

Schweigert, G. and Koppka, J. 2011. Decapods (Crustacea: Brachyura) from the Jurassic of Germany and Lithuania, with descriptions of new species of Planoprosopon and Tanidromites. Neues Jahrbuch für Geologie und Paläontologie - Abhandlungen, 260(2):203-210.

Schweitzer, C.E and Feldmann, R.M. 2008. A new Classification for some Jurassic Brachyura (Crustacea: Decapoda: Brachyura: Homolodromioidea): Families Goniodromitidae Beurlen, 1932 and Taniodromitidae new family. Senckenbergiana lethaea, 87(2):119156.

Schweitzer, C.E. and Feldmann, R.M. 2009. Revision of Gabriella Collins et al., 2006 (Decapoda: Brachyura: Tanidromitidae) with new Jurassic species. Neues Jahrbuch für Geologie und Paläontologie, Abhandlungen, 252(1):1-16.

Schweitzer, C.E. and Feldmann, R.M. 2010. Revision of Cycloprosopon and additional notes on Eodromites (Brachyura: Homolodromioidea: Goniodromitidae).
Annalen des Naturhistorischen Museums in Wien, 112:169-194.

Schweitzer, C.E., Feldmann, R.M., Garassino, A., Karasawa, H. and Schweigert, G. 2010. Systematic list of fossil crustacean species. Crustaceana Monographs, 10:I-VII + 222 pp.; Leiden \& Boston (Brill).

Schweitzer, C.E. Feldmann, R.M. and Lazăr, I. 2007. Decapods from Jurassic Oxfordian sponge megafacies of Dobrogea, Romania and reconsideration of Nodoprosopon Beurlen, 1928. Neues Jahrbuch für Geologie und Paläontologie, Abhandlungen, 244(1):99-113.

Starzyk, N. 2013. Jurassic crabs: new characters of carapace diagnostic to known tanidromitid species. Neues Jahrbuch für Geologie und Paläontologie Abhaldungen, 269(2):173-187.

Starzyk, N., Krzemińska, E. and Krzemiński, W. 2011. Intraspecific variation in the Jurassic crab Bucculentum bucculentum (Decapoda: Homolodromioidea: Bucculentidae). Neues Jahrbuch für Geologie und Paläontologie, Abhandlungen, 260(2):203-210.

Starzyk, N., Krzemińska, E. and Krzemiński, W. 2012. A new crab species from the Oxfordian of Poland (Decapoda: Brachyura: Goniodromitidae). Neues Jahrbuch für Geologie und Paläontologie, Abhandlungen, 263(2):143-153.

Van Straelen, V. 1925. Contribution à l'étude des crustacés décapodes de la période Jurassique. Mémoires de l'académie royale de Belgique, 7:1-481.

von Meyer, H. 1835. Briefliche Mitteilungen. Neues Jahrbuch für Mineralogie, Geognosie, Geologie und Petrefakten-Kunde, 1-329.

von Meyer, H. 1840. Neue Gattungen fossiler Krebse aus Gebilden vom bunten Sandsteine bis in die Kreide. Stuttgart (E. Schweizerbart).

von Meyer, H. 1842. Über die in dem dichten Jurakalk von Aalen in Württemberg vorkommend Spezies des Crustaceengenus Prosopon. Beiträge zur Petrefactenkunde, 5:70-75.

von Meyer, H. 1857. Briefliche Mittheilungen, an Prof. BRONN gerichtet. Neues Jahrbuch für Mineralogie, Geognosie, Geologie und Petrefaktenkunde, 1-556.

von Meyer, H. 1860. Die Prosoponiden oder die Familie der Maskenkrebse. Palaeontographica, 7:183-222.

Wehner, G. 1988. Über die Prosoponiden (Crustacea, Decapoda) des Jura. Dissertation zur Erlangung des Doktorgrades der Fakultät für Geowissenschaften der Ludwig-Maximilians-Universität zu München; München (published by the author).

Withers, T.H. 1951. Some Jurassic and Cretaceous crabs (Prosoponidae). Bulletin of the British Museum (Natural Hostory), Geology, 1(6):171-186. 